\title{
Penerapan Metode Weighted Product Pada Sistem Penentuan Dosen Pembimbing Dan Penguji Skripsi
}

\author{
Renny Puspita Sari ${ }^{* 1}$, Ibnur Rusi ${ }^{2}$, Ferdy Febriyanto ${ }^{3}$ \\ ${ }^{1,2,3}$ Sistem informasi, Fakultas Matematika dan Ilmu Pengetahuan Alam, Universitas \\ Tanjungpura, Pontianak, Indonesia \\ e-mail: *11 rennysari@sisfo.untan.ac.id, ${ }^{2}$ ibnurrusi@sisfo.untan.ac.id, ${ }^{3}$ Ferdyf@ sisfo.untan.ac.id
}

\begin{abstract}
Abstrak
Dosen pembimbing dan penguji skripsi sebagai salah salah satu tugas akhir untuk seorang mahasiswa sangatlah penting karena berperan sebagai pengarah, fasilitator, serta memberikan motivasi. Penentuan dosen pembimbing dan penguji pada Jurusan Sistem Informasi Fakultas Matematika dan Ilmu Pengetahuan Alam (MIPA) masih dilakukan melalui rapat internal jurusan. Hal tersebut kurang efektif dan efisien mengingat jumlah mahasiswa yang mengajukan tugas akhir sangat banyak, judul tugas akhir mahasiswa yang sangat beragam, serta dosen pembimbing dan penguji dengan kompetensi yang berbeda-beda. Hasil akhir sistem dapat menunjukkan urutan ranking dosen pembimbing dan penguji skripsi dengan metode Weighted Product, selain itu juga pada sistem ini nantinya akan memberikan informasi jumlah mahasiswa yang dibimbing, mahasiswa yang di uji dan jumlah mahasiswa yang selesai dibimbing oleh dosen yang bersangkutan. Sistem dapat juga mencetak berita acara pelaksanaan skripsi yang terbagi menjadi seminar proposal, seminar hasil dan sidang sarjana dimana secara otomatis sudah dilengkapi nama dosen pembimbing dan penguji. Dengan dibangunnya sistem ini harapannya dapat membantu memudahkan jurusan ketika akan menentukkandosen pembimbing dan penguji skripai serta memudahkan proses administrasi tugas akhir di Jurusan Sistem Informasi Fakultas MIPA Universitas Tanjungpura.
\end{abstract}

Kata kunci-Sistem Pendukung Keputusan, Weighted Product, Dosen Pembimbing, Dosen Penguji, Skripsi.

\begin{abstract}
The supervisor and thesis examiner for a student is very important because it acts as a guide, facilitator, and provides motivation. Determination of supervisors and examiners at the Department of Information Systems, Faculty of Mathematics and Natural Sciences (MIPA) is still being carried out through internal department meetings. This is less effective and efficient considering the large number of students who submit final assignments, the titles of students' final assignments are very diverse, as well as supervisors and examiners with different competencies. The final result of the system can show the ranking order of the supervisor and thesis examiners with the Weighted Product method, besides that this system will also provide information on the number of students being mentored, students being tested and the number of students who have been supervised by the lecturer concerned. The system can also print the minutes of the thesis implementation which are divided into proposal seminars, result seminars and undergraduate sessions which automatically include the names of the supervisors and examiners. With the construction of this system, it is hoped that it can help make it easier for the department to determine the supervisor and examiner of the final project and facilitate the administrative process of the final project in the Information Systems Department, Faculty of Mathematics and Natural Sciences, Tanjungpura University.
\end{abstract}

Keywords - Decision Support System, Weighted Product, supervisor lecturer, examiner, Thesis 


\section{PENDAHULUAN}

Perkembangan teknologi dan informasi yang cukup cepat di bidang pendidikan dapat berkontribusi terhadap sistem pelayanan berbasis komputer yang lebih maksimal. Pesatnya perkembangan teknologi saat ini memicu suatu perguruan tinggi yang terdiri dari fakultas dan jurusan bidang studi untuk menemukan berbagai solusi pemecahan masalah dalam mendukung proses pendidikan. Jurusan Sistem Informasi Universitas Tanjungpura merupakan salah jurusan di Fakultas Matematika dan Ilmu Pengetahuan Alam (FMIPA) yang memfokuskan diri terhadap perkembangan teknologi dan informasi khususnya proses pembelajaran terkait skripsi mahasiswa. Setiap mahasiswa FMIPA yang akan menyelesaikan studinya wajib membuat tugas akhir dalam bentuk skirpsi [1]. Dalam penyusunan tugas akhir dalam hal ini skripsi, mahasiswa membutuhkan dosen pembimbing dan penguji yang berperan sebagai pengarah, fasilitator, serta memberikan motivasi [2].

Saat ini, penentuan dosen pembimbing dan penguji pada Jurusan Sistem Informasi FMIPA Universitas Tanjungpura masih dilakukan melalui rapat internal jurusan. Hal tersebut kurang efektif dan efisien mengingat jumlah mahasiswa yang mengajukan skripsi sangat banyak, judul tugas akhir mahasiswa yang sangat beragam, serta dosen pembimbing dan penguji dengan kompetensi yang berbeda- beda. Oleh karena itu diperlukan sistem untuk menentukan dosen pembimbing dan penguji tugas akhir/skripsi mahasiswa dengan Metode Weighted Product (WP) agar dapat memberikan penilaian terkait penentuan dosen pembimbing sehingga proses pembimbingan serta pengujian nantinya menjadi lebih maksimal dan tidak menemui banyak kendala.

Metode WP ini dipilih karena metode WP ini merupakan salah satu bagian dari model MADM (Multi-Attribute Decision Making) yaitu setiap atribut kriteria ditentukan bobot kepentingannya untuk menyeleksi alternative menghasilkan proses perangkingan [3]. Adapun kriteria yang digunakan pada kasus penentuan dosen pembimbing dan penguji tidak hanya memperhatikan kompetensi dari dosen saja, tetapi juga aspek-aspek lainnya seperti rasio jumlah dosen dengan jumlah mahasiswa yang sedang dibimbing sehingga proses bimbingan tiap mahasiswa nantinya menjadi lebih optimal. Selain itu, sistem ini juga memperhatikan beban kerja dosen (SKS), pendidikan, status, pengalaman pembimbing, layanan konsultasi, waktu bimbingan rata-rata per mahasiswa, serta jumlah bimbingan tugas akhir yang sudah selesai.

\subsection{Penelitian Terdahulu}

Terdapat beberapa peneliti telah melakukan penelitian terkait penentuan dosen pembimbing tugas akhir yang difokuskan hanya pada satu metode saja yang digunakan untuk menentukan dosen pembimbing tugas akhir, seperti yang disebutkan dalam Abdullah dan Pangestika [4] yang menggunakan metode AHP, selain itu juga terdapat metode SMART oleh Situmorang et al. [5], metode SAW oleh septian et al.[6], serta metode WP yang disebutkan dalam Purba [7]. Adapula peneliti yang menggabungkan metode Weighted Product dan Winnowing dalam penentuan dosen pembimbing seperti yang dijelaskan pada penelitian putri et al. [8]. Namun ada juga penelitian yang menggunakan metode WP pada topik berbeda yaitu penerimaan karyawan seperti yang disebutkan dalam Stephano dan Sari [9].

Dengan melihat beberapa refrensi jurnal diatas, maka dapat disimpulkan bahwa masih banyak ditemukan kesulitan dalam menentukkan dosen pembimbing dan penguji tugas akhir mahasiswa secara manual, sehingga dapat menghambat proses pengerjaan tugas akhir mahasiswa. Penelitian ini bermaksud untuk menerapkan metode WP dalam penentuan dosen pembimbing skripsi pada Jurusan Sistem Informasi (MIPA) yang terkomputerisasi dalam melakukan perhitungan yang komprehensif berdasarkan kriteria dan faktor kompetensi masingmasing dosen. Perbedaan Penelitian yang dilakukan saat ini dengan penelitian yang sudah dilakukan sebelumnya yaitu terletak pada hasil akhir penelitian. 
Hasil penelitian ini menunjukkan urutan ranking dosen pembimbing dan penguji tugas akhir dengan metode WP, selain itu juga pada sistem ini nantinya akan memberikan informasi jumlah mahasiswa yang dibimbing, mahasiswa yang diuji dan jumlah mahasiswa yang selesai dibimbing oleh masing-masing dosen. Ketika sudah ditentukan nama dosen pembimbing dan penguji maka admin pada sistem dapat juga mencetak berita acara pelaksanaan tugas akhir yang terbagi menjadi seminar proposal, seminar hasil dan sidang sarjana dimana secara otomatis sudah dilengkapi nama dosen pembimbing dan penguji dari penentuan hasil akhir ranking perhitungan. Pada penelitian ini diharapkan bisa memberikan solusi untuk meningkatkan pelayanan administrasi tugas akhir pada jurusan sistem informasi Fakultas MIPA secara online dan terkomputerisasi dengan baik.

\section{METODE PENELITIAN}

Kerangka kerja penelitian menggunakan perancangan penelitian Sistem Informasi atau biasa lebih dikenal dengan Framework Hevner. Framework ini umumnya digunakan dalam penelitian Sistem Informasi (SI) [12]. Kerangka ini digunakan untuk menggambarkan lingkungan penelitian, fase - fase yang dilalui dalam penelitian, basis pengetahuan yang digunakan, dan kontribusi yang dihasilkan dari penelitian ini. Kerangka kerja penelitian dapat dilihat pada Gambar 1 dibawah ini:

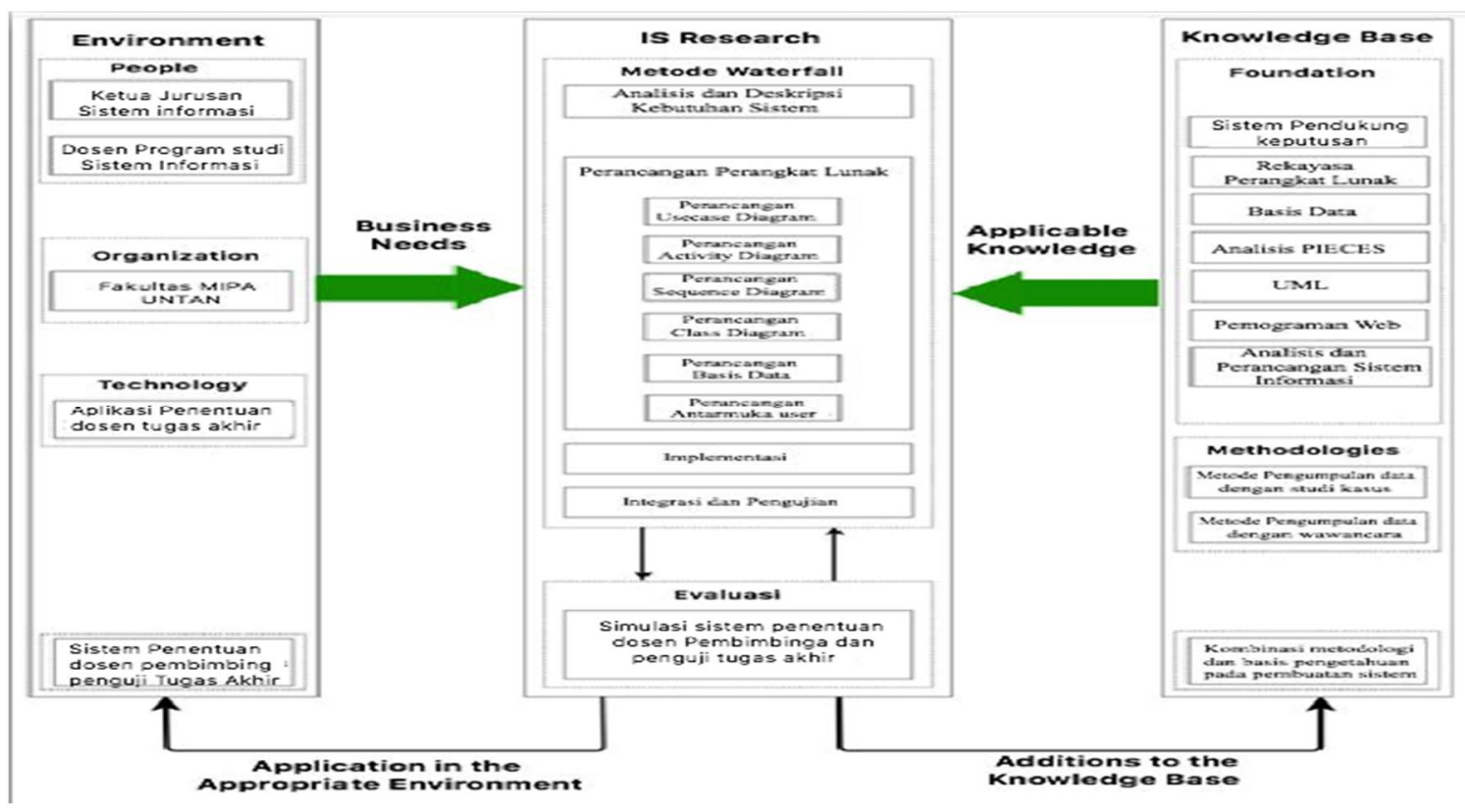

Gambar 1. Metodelogi Penelitian

Metode penelitian menggunakan framework Hevner terbagi menjadi 3 bagian yaitu bagian pertama menggambarkan lingkungan (Environmnet) yang terdiri dari orang yaitu ketua jurusan dan dosen dosen sistem informasi. Selain itu juga terdapat organisasi berupa Fakultas MIPA Universitas Tanjungpura, serta teknologi yaitu berupa Aplikasi Penentuan dosen pembimbing dan penguji tugas akhir. Bagian berikutnya IS Research berupa fase - fase yang dilalui dalam tahapan pengembangan perangkat lunak antara lain analisis kebutuhan sistem yang mendefinisikan kebutuhan pengembangan perangkat lunak berupa fungsional dan non fungsional dalam pengembangan, selanjutnya Perancangan perangkat lunak yaitu proses 
perancangan UML dengan merancangan menggunakan usecase, activity, sequence diagram, basis data serta peracangan antarmuka. Selanjutnya Tahap implementasi rancangan yang dipindahkan menggunakan bahasa pemograman dan yang terakhir yaitu proses pengujian sistem yang telah dibuat yang disebut dengan tahap Pengujian.

Bagian terakhir terdiri dari basis pengetahuan yang digunakan untuk mendukung penelitian ini antara lain Analisis dan Perancangan Sistem Informasi, Sistem Pendukung keputusan, Rekayasa Perangkat Lunak, Pemogrman web, Analisis PIECES, Basis data, dan terakhir UML.

Sehingga kontibusi yang dihasilkan dari penelitian ini adalah dengan dibangun suatu sistem untuk menentukan dosen pembimbing dan penguji skripsi jurusan Sistem Informasi di Fakultas MIPA Universitas Tanjungpura memberikan tiga manfaat dari berbagai sisi antara lain manfaat untuk lingkungan Jurusan Sistem Informasi Fakultas MIPA Universitas Tanjungpura adalah meringankan beban kerja Ketua Jurusan dan administrasi jurusan dalam menentukan dan mengelola pendataan dosen pembimbing dan penguji mahasiswa, manfaat berikutnya dapat dirasakan dari bidang ilmu Sistem Informasi yaitu menambah pengetahuan dalam merancang suatu sistem penentuan dosen pembimbing dan penguji skripsi dan memperkenalkan kepada masyarakat bahwa sistem informasi dapat memberikan solusi masalah dengan teknologi informasi. Sedangkan yang terakhir manfaat yang diperoleh oleh peneliti adalah mendapatkan pelajaran baru tentang proses penentuan dosen pembimbing dan penguji skripsi dengan metode Weighted Product (WP) serta menambah pengalaman melakukan perancangan sistem pendukung keputusan ketika akan menentukan dosen pembimbing dan penguji skripsi mahasiswa Jurusan Sistem Informasi di Fakultas MIPA Universitas Tanjungpura.

\subsection{Skripsi, Dosen Pembimbing dan Penguji}

Skripsi dapat diartikan sebagai sebuah karya ilmiah yang harus dikerjakan untuk mendapatkan status sarjana sebagai persyaratan di setiap Perguruan Tinggi Negri (PTN) maupun Perguruan Tinggi Swasta (PTS) [10]. Tujuan yang ingin dicapai oleh seorang mahasiswa adalah menjadi sarjana, sementara salah satu syarat menjadi sarjana dibeberapa perguruan tinggi adalah mahasiswa yang bersangkutan harus mampu melakukan penelitian dan sekaligus menyusun laporan hasil penelitian dalam bentuk sebuah karya tulis ilmiah yang disebut skripsi, tesis atau Disertasi [2].

Dosen pembimbing berperan sangat penting dalam membantu mahasiswa ketika akan menyelesaikan tugas akhir, selain itu juga memberikan arahan kepada mahasiswanya terkait konsep dan kerangka penelitian yang dilakukan. Judul tugas akhir yang diajukan mahasiswa harus sesuai dengan bidang ilmu dosen pembimbing [5]. Maka seorang mahasiswa hendaknya menyerahkan sepenuhnya apa yang disarankan atau dikritik oleh dosen pembimbing atau penguji kepadanya, mengingat dosen pembimbing atau dosen penguji sesungguhnya memiliki kemampuan untuk memikirkan apa yang terbaik untuk skripsi, tesis atau disertasi yang ditulis oleh mahasiswa yang bersangkutan [2].

\subsection{Metode Weight Product}

Metode weight product (WP) adalah suatu metode dengan mengalikan antara rating dan atribut, metode ini cukup sederhana karena bobot atribut akan di pangkatkan dengan setiap atribut yang ada, proses perpangkatan ini dikebal dengan nama normalisasi [11]. Metode ini dikatakan sederhana karena urutan penyelesaian metode weight product ini cukup singkat yaitu Metode weight product dimulai dari melakukan defenisi terkait kriteria yang nantikan akan digunakan sebagai syarat pergitungan penyelesaian masalah, selanjutnya setelah mendefeniskan kritria yang digunakan selanjutnya melakukan normalisasi dari setiap nilai alternatif yang sudah ada. Dari hasil normalisasi inilah nantinya setiap alternatif dapat dihitung nilai bobot prefensinya. Dan yang terakhir setelah semua langkah dilakukan maka selanjutnya akan 
menghasilkan rangking urutan alternatif terbaik yang dipilih. Dibawah ini dapat dilihat persamaan yang digunakan untuk menenukan normalisasi pada setiap nilai alternatif.

$$
S_{i}=\prod_{j=1}^{n} X_{i j}^{w_{i j}}
$$

Dimana $\sum w j=w j$ adalah pangkat bernilai positif untuk atribut keuntungan (benefit), dan bernilai negatif untuk atribut biaya (Cost). Sedangkan untuk menghitung nilai bobot preferensinya, diberikan sebagai berikut:

$$
V_{i}=\frac{\prod_{j=1}^{n} X_{i j}^{w_{i j}}}{\prod_{j=1}^{n}\left(X_{j}^{*}\right)^{w_{j}}}
$$

\section{HASIL DAN PEMBAHASAN}

\subsection{Perancangan dan Implemntasi Sistem}

Awal penelitian ini berupa fase - fase yang dilalui dalam tahapan pengembangan perangkat lunak berdasarkan metodologi yang sudah dibuat sebelumnya yaitu pada bagian $I S$ Research bagian Analisis Kebutuhan sistem menggunakan framework Analisis Performance, Information, Economy, Controll, Efeciency, Service (PIECES). Untuk melihat perbandingan antara sistem lama secara konvensional dengan sistem baru berbasis komputer terdapat pada table 1 dibawah ini :

\begin{tabular}{|c|c|}
\hline \multicolumn{2}{|c|}{ Analisis Kinerja (Performance) } \\
\hline Sistem Lama & Sistem Baru \\
\hline $\begin{array}{l}\text { Untuk menentukan dosen pembimbing dan } \\
\text { penguji skripsi harus dilakukan rapat atau } \\
\text { tatap muka secara langsung diantara } \\
\text { pengambil keputusan yaitu ketua jurusan } \\
\text { dan dosen. }\end{array}$ & $\begin{array}{l}\text { Sistem yang baru dapat diakses secara online } \\
\text { karena berbasis web dan dapat diakses secara } \\
\text { online, sehingga pengambil keputusan } \\
\text { memberikan bobot kepentingan melalui aplikasi }\end{array}$ \\
\hline \multicolumn{2}{|c|}{ Analisis Informasi (Information) } \\
\hline Sistem Lama & Sistem Baru \\
\hline $\begin{array}{l}\text { Pengambil keputusan bisa saja mendapatkan } \\
\text { informasi dosen pembimbing dan penguji } \\
\text { yang kurang akurat ketika banyaknya data } \\
\text { mahasiswa yang mengajukan proses tugas } \\
\text { akhir. }\end{array}$ & $\begin{array}{l}\text { Pada sistem yang baru data dosen pembimbing } \\
\text { dan penguji disimpan di dalam sistem dengan } \\
\text { ID yang unik sehingga meminimalisir } \\
\text { tertukarnya data dosen pembimbing maupun } \\
\text { penguji. }\end{array}$ \\
\hline \\
\hline \multicolumn{2}{|c|}{ Analisis Ekonomi (Economy) } \\
\hline $\begin{array}{l}\text { Pada sistem yang lama memerlukan biaya } \\
\text { yang cukup banyak untuk menyediakan } \\
\text { kertas dan ruang penyimpanan arsip }\end{array}$ & $\begin{array}{l}\text { Pada sistem yang baru data mahasiswa tugas } \\
\text { akhir beserta pembimbing dan penguji disimpan } \\
\text { di dalam database sistem sehingga lebih } \\
\text { menghemat biaya penyediaan kertas dan ruang } \\
\text { penyimpanan arsip }\end{array}$ \\
\hline \multicolumn{2}{|c|}{ Analisis Kontrol (controll) } \\
\hline Sistem Lama & Sistem Baru \\
\hline $\begin{array}{l}\text { Resiko pengambilan keputusan di } \\
\text { pengaruhi pihak luar ataupun yang bersifat }\end{array}$ & $\begin{array}{l}\text { Dengan sistem yang baru hanya pengambil } \\
\text { keputusan yang sudah terdaftar yang dapat }\end{array}$ \\
\hline
\end{tabular}

Tabel 1. Perbandingan Sistem Lama dan Sistem Baru Menggunakan PIECES

Renny, et., al [Penerapan Metode Weighted Product pada Sistem Penentuan Dosen Pembimbing dan Penguji Skripsi] 


\begin{tabular}{|l|l|}
\hline subjektif cukup tinggi. & $\begin{array}{l}\text { memberikan bobot kepentingan dalam } \\
\text { menyeleksi dosen pembimbing dan penguji }\end{array}$ \\
\hline \multicolumn{1}{|c|}{ Analisis Efisiensi (effeciency) } \\
\hline \multicolumn{1}{|c|}{ Sistem Lama } & \multicolumn{1}{c|}{ Sistem Baru } \\
\hline $\begin{array}{l}\text { Pada sistem yang lama harus melakukan } \\
\text { pemeriksaan secara berulang ketika terjadi } \\
\text { kesalahan, sehingga akan memakan banyak } \\
\text { waktu. }\end{array}$ & $\begin{array}{l}\text { Pada sistem yang baru penyeleksian dilakukan } \\
\text { secara terkomputerisasi sehingga meminimalisir } \\
\text { tingkat kesalahan, mempersingkat waktu, dan } \\
\text { data hitungan penyeleksian ditampilkan secara } \\
\text { detail jika akan dilakukan peninjauan kembali }\end{array}$ \\
\hline \multicolumn{2}{|c|}{ Analisis Layanan (Service) } \\
\hline $\begin{array}{l}\text { Sistem Lama Sistem Baru } \\
\text { Pada sistem yang lama layanan informasi } \\
\text { dibatasi hari kerja atau waktu istirahat. }\end{array}$ & $\begin{array}{l}\text { Pada sistem yang baru layanan infomasi } \\
\text { dilakukan sepenunya oleh sistem sehingga tidak } \\
\text { terbatas oleh waktu kerja maupun waktu } \\
\text { istirahat. }\end{array}$ \\
\hline
\end{tabular}

Selanjutnya perancangan perangkat lunak yaitu proses perancangan UML yang dimulai dengan pembuatan Use case diagram untuk menjelaskan user yang berhak menggunakan fungsi fungsi pada sistem tersebut serta mendefeniskan fungsi yang terdapat didalam sistem tersebut [13]. Pada perancangan sistem ini terdapat dua orang aktor yaitu Administrator, dan decisioan maker yaitu ketua jurusan Sistem Informasi. Untuk melihat secara keseluruhan fungsi-fungsi beserta aktor yang bertanggung jawab pada masing-masing fungsi eleman sistem yang di rancang serta salah satu fungsi yang dilakukan admin yaitu mengelola data dosen pada gambar 2 dan merubah data dosen pada gambar 3 dibawah ini:

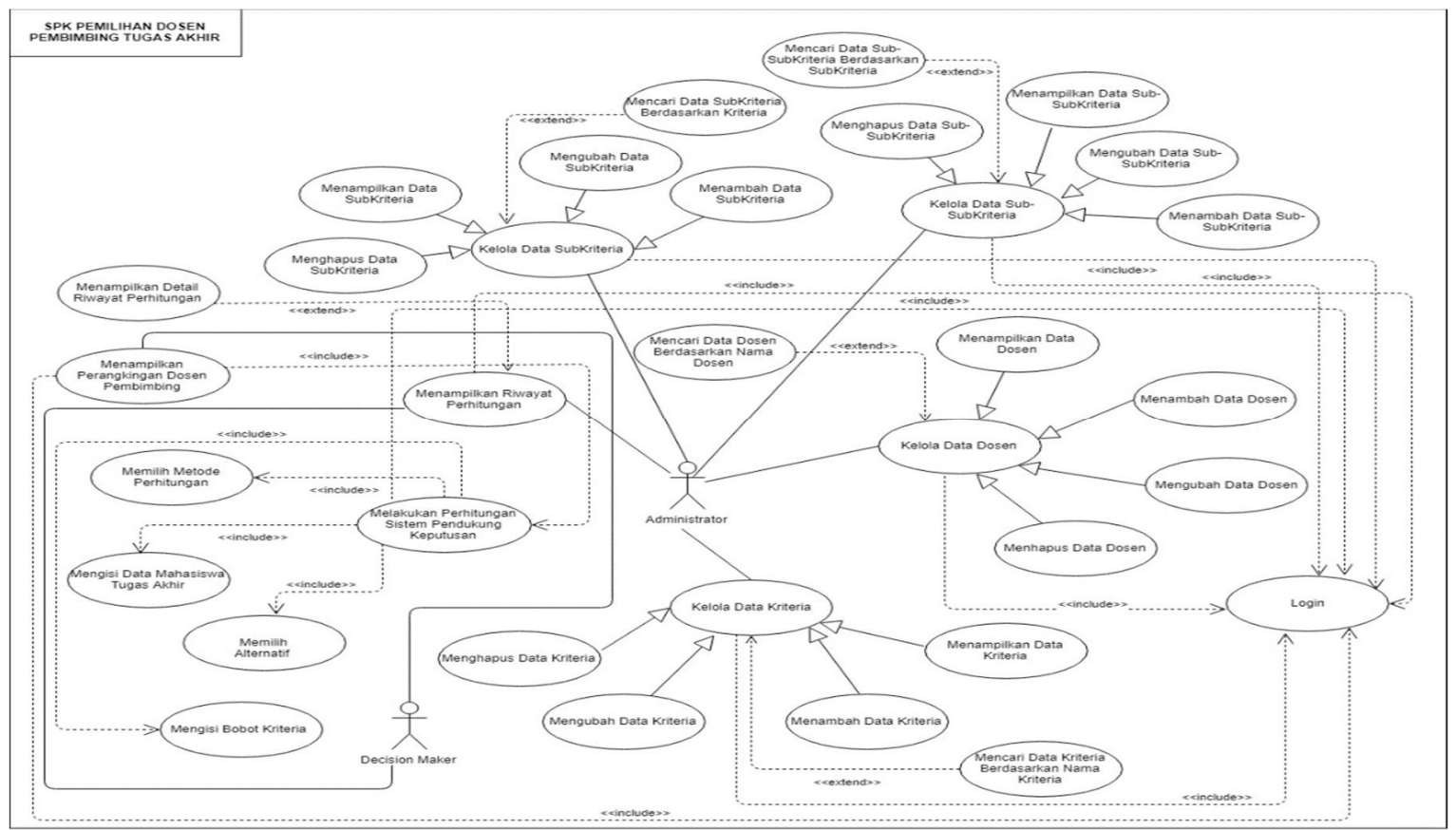

Gambar 2. Usecase Diagram 


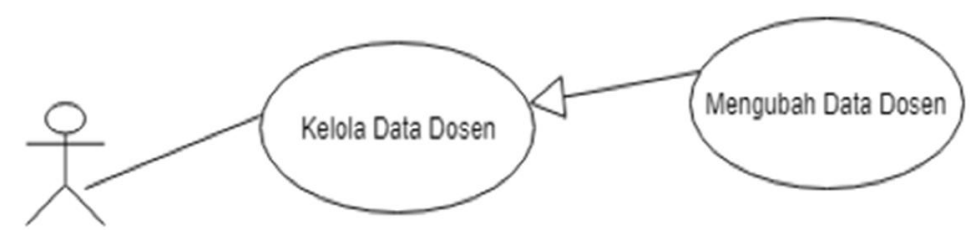

Administrator

Gambar 3. Usecase Mengubah Data Dosen

Proses perancangan berikutnya yaitu menggambarkan diagram berupa aliran aktivitas sistem, selain itu juga dapat menggambarkan proses yang dapat terjadi secara bersamaan pada beberapa aliran aktivitas yang dikenal dengan activity diagram [13]. Dapat dilihat pada gambar 4. Activity diagram mengubah data dosen dibawah ini menjelaskan mengenai alur aktivitas yang terjadi antara aktor dan sistem pada saat melakukan perubahan data dosen. Aktivitas pada diagram ini mencerminkan alir kejadian proses kegiatan yang terdapat pada alur dasar spesifikasi usacase yang kemudian dimodelkan menggunakan activity diagram.

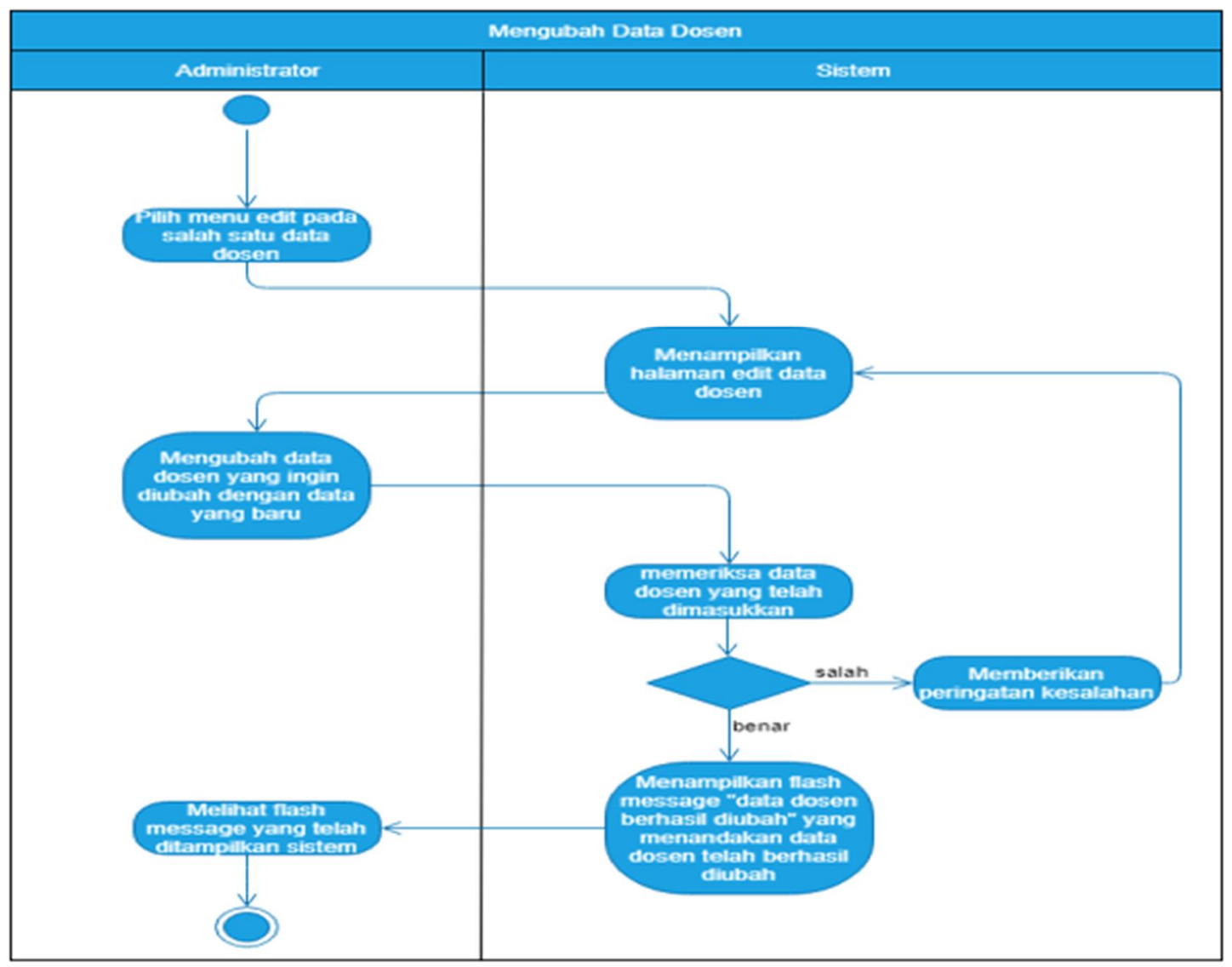

Gambar 4. Activity Diagram Mengubah Data Dosen

Selanjutnya perancangan Sequence Diagram yang berupa pengiriman dan penerimaan pesan dari objek sat uke objek lain serta mendeskripsikan waktu hidup juga prilaku objek pada use case.Banyaknya jumlah usecase diagram yang dibuat akan sama dengan jumlah sequenc ediagram yang harus digambarkan [13]. Dapat dilihat pada gambar 5 dibawah ini menampilkan interaksi admin dan sistem ketika melakukan perubahan data dosen. 


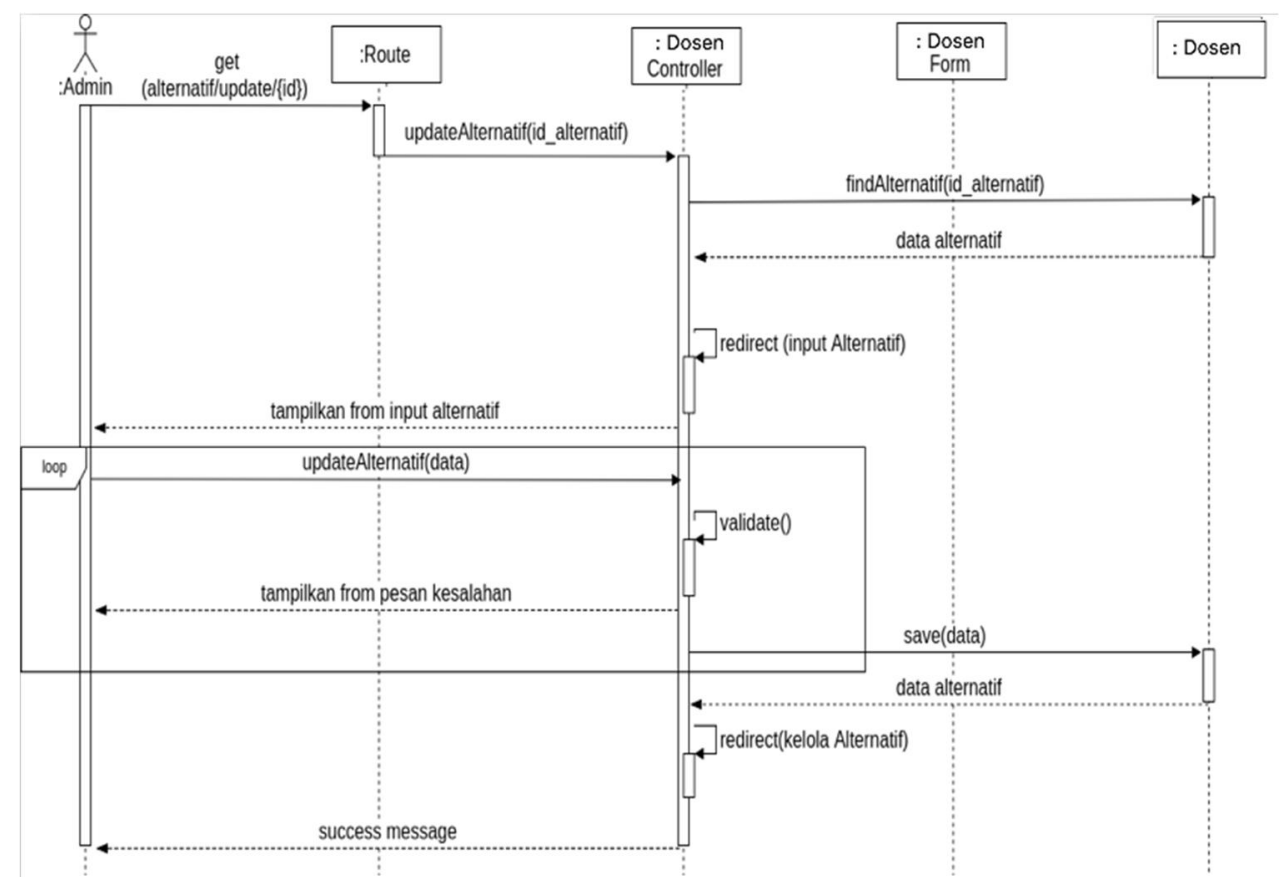

Gambar 5. Sequence Diagram Mengubah Data Dosen

Perancangan akhir UML yaitu membuat struktur sistem yang digambarkan dari sudut pandang pendefenisian kelas ketika akan membangun suatu sistem. Diagram class dapat menunjukan berbagai macam hubungan objek mulai dari Batasan, hubungan objek, operasi dan property sebuah class [13]. Terdapat enam class pada sistem ini yaitu Dosen, kriteria, himpunan sub krtiteria, himpunan sub sub kriteria, nilai perhitungan, dan data mahasiswa TA (Tugas Akhir). Untuk lebih jelas Class diagram terdapat pada gambar 6.

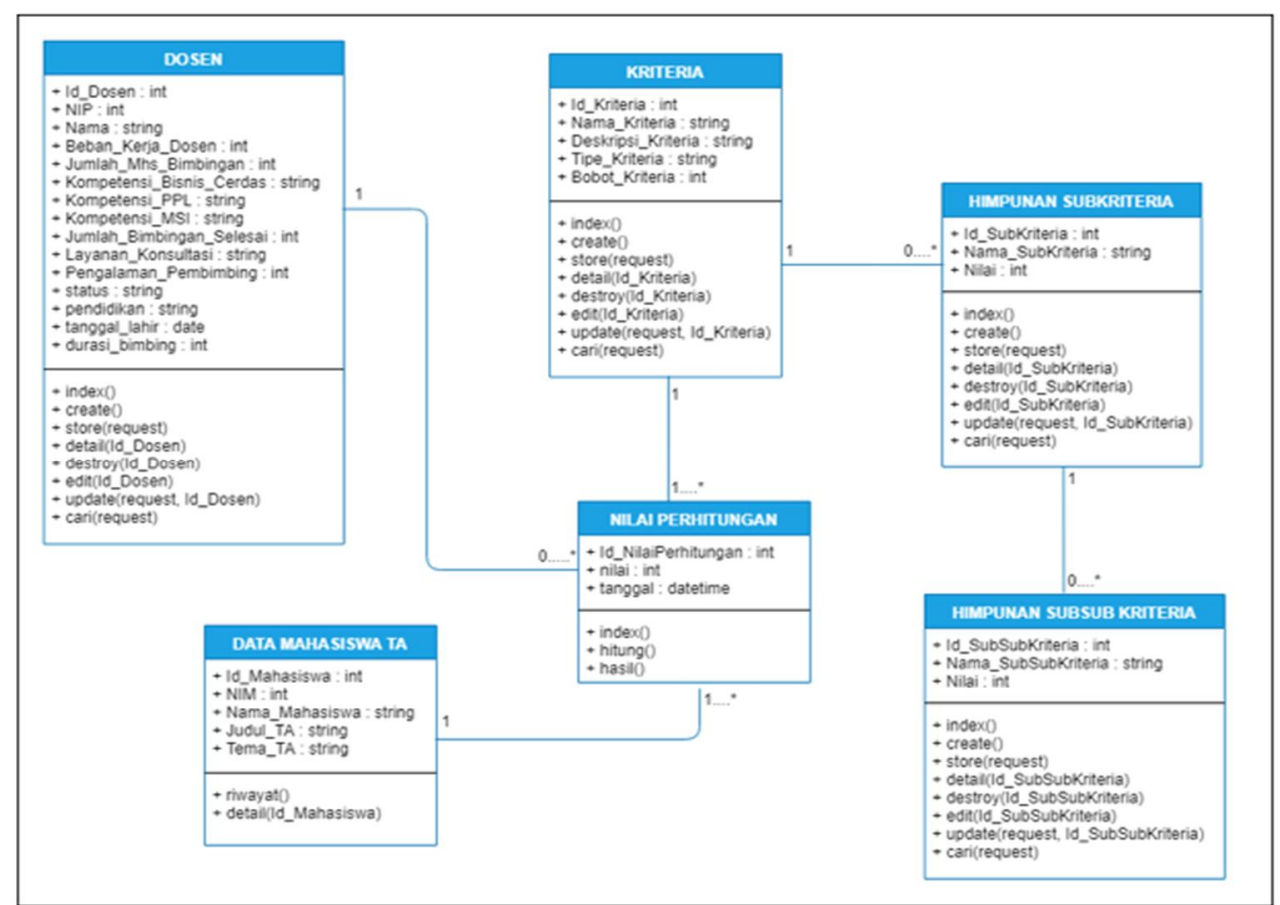

Gambar 6. Class Diagram

Renny, et., al [Penerapan Metode Weighted Product pada Sistem Penentuan Dosen Pembimbing dan Penguji Skripsi] 
Entity Relationship Diagram (ERD) sebagai salah satu bentuk perancangan basis data yang menampilkan diagram atau gambar yang menunjukkan sistem bisnis yang digunakan terkait dalam pembuatan, penyimpanan serta penggunaannya [13]. Untuk lebih jelas ERD terlihat pada gambar 7 .

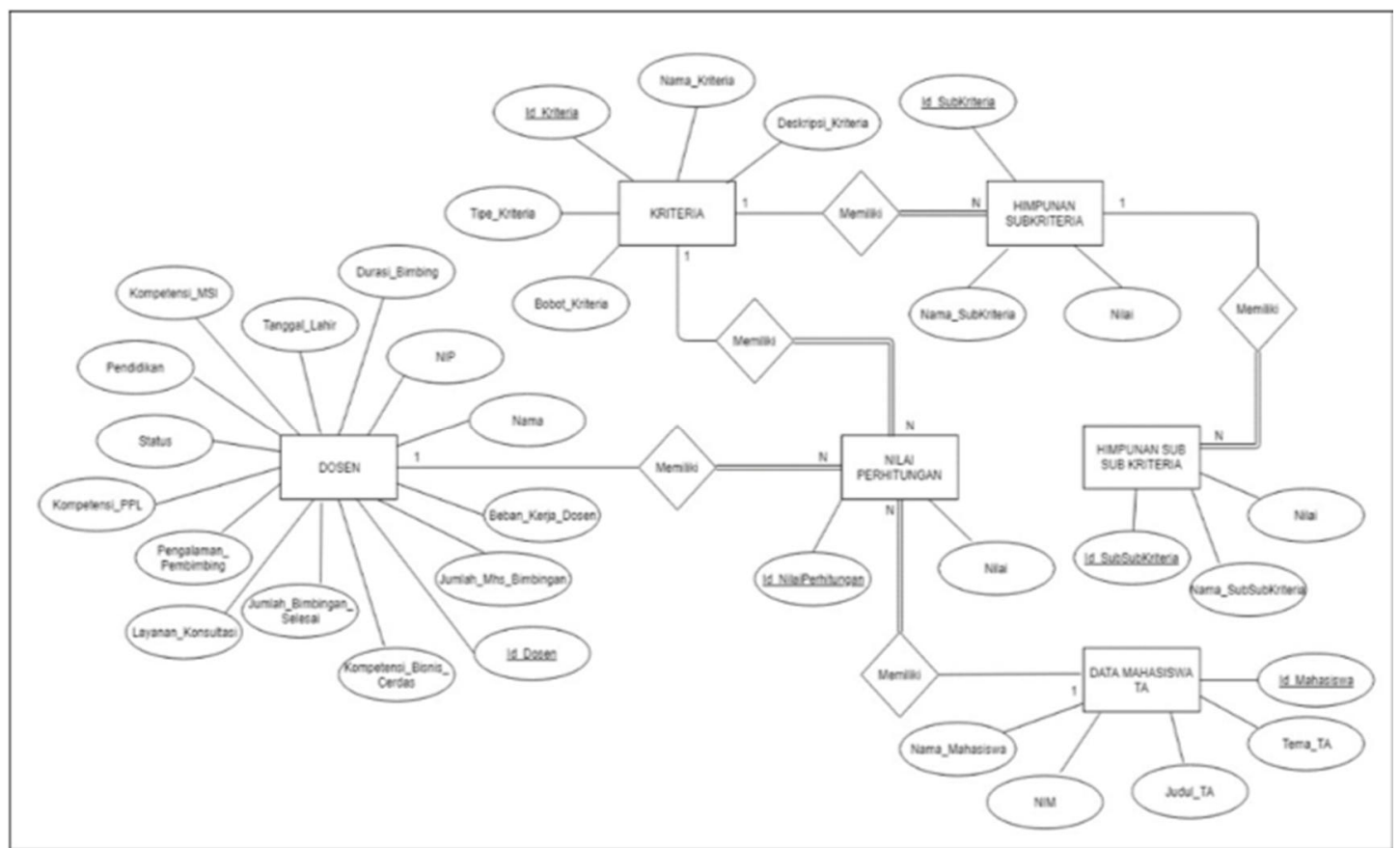

Gambar 7. Entity Relationship Diagram (ERD)

Selanjutnya Tahap implementasi sistem yang sudah dibuat dalam bentuk website terdapat pada gambar 8 serta gambar 9 dibawah ini:

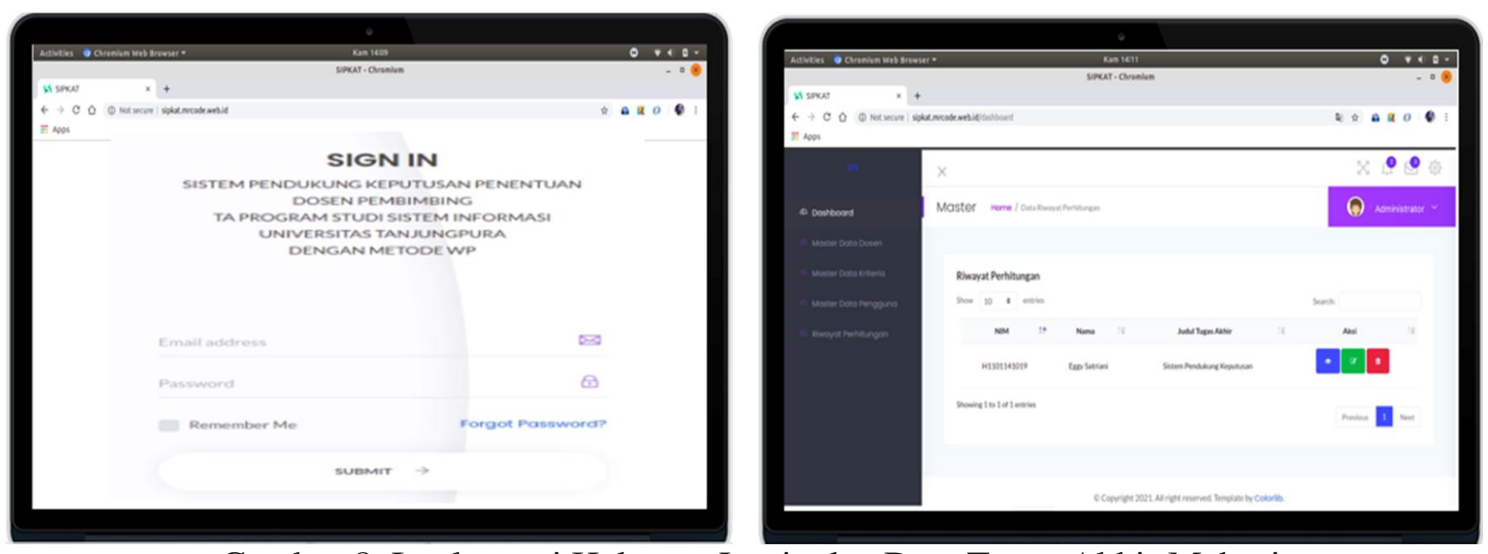

Gambar 8. Implemtasi Halaman Login dan Data Tugas Akhir Mahasiswa

Gambar 8 tampilan untuk melakukan login oleh semua user agar bisa masuk ke dalam sistem serta tampilan sistem yang memuat data- data mahasiswa yang mengajukan tugas skipsi. 

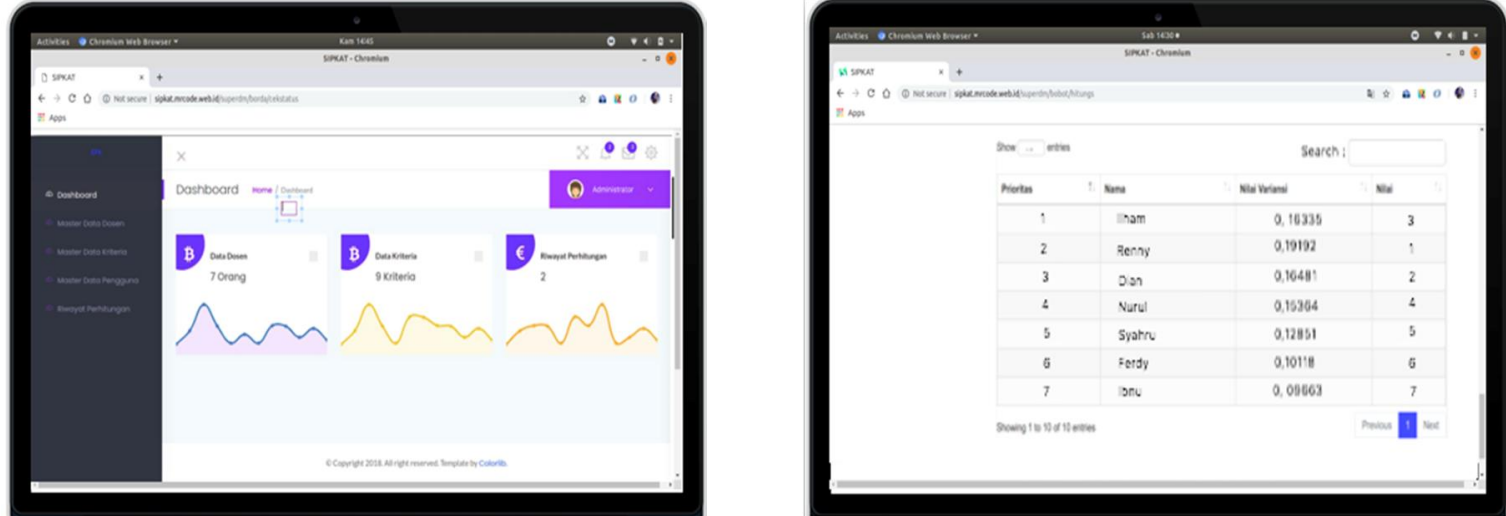

Gambar 9. Implemtasi Halaman Data Tugas Akhir Mahasiswa dan Tampilan Perhitungan

Gambar 9 menampilkan tampilan perhitungan oleh administrator untuk melihat data tugas akhir dan perhitungan yang sudah dilakukan.

\subsection{Penerapan Metode Weighted Product (WP)}

Proses perhitungan manual menggunakan sampel data dosen jurusan Sistem Informasi sebagai dosen pembimbing dan penguji serta data penilaian dosen yang dimulai dengan menentukan kriteria. Kriteria penilaian tersedia pada pada Tabel 2

Tabel 2. Kriteria Penilaian

\begin{tabular}{|c|c|c|}
\hline \multicolumn{3}{|c|}{ Kriteria } \\
\hline C1 & Beban Kerja Dosen (SKS) & Cost \\
\hline C2 & Jumlah Mahasiswa Bimbingan & Cost \\
\hline C3 & Jumlah Bimbingan Selesai & Benefit \\
\hline C4 & Kompetensi & Benefit \\
\hline C5 & Pendidikan & Benefit \\
\hline C6 & Status Pekerjaan & Benefit \\
\hline C7 & Pengalaman Pembimbing & Benefit \\
\hline C8 & Durasi Setiap Bimbingan & Benefit \\
\hline C9 & Layanan Konsultasi & Benefit \\
\hline
\end{tabular}

Selanjutnya dilakukan penilaian terhadap calon dosen pembimbing tugas akhir berdasarkan masing-masing kriteri, kemudian dilakukan konversi kedalam nilai kriteria dengan hasil yang ditunjukkan pada tabel 3 .

Tabel 3. Metode WP

\begin{tabular}{|c|c|c|c|c|c|c|c|c|c|}
\hline \multicolumn{10}{|c|}{ Metode WP } \\
\hline $\begin{array}{c}\text { Nama } \\
\text { alternatif }\end{array}$ & $\mathrm{C} 1$ & $\mathrm{C} 2$ & $\mathrm{C} 3$ & $\mathrm{C} 4$ & $\mathrm{C} 5$ & C6 & C7 & $\mathrm{C} 8$ & C9 \\
\hline Ilham & 4 & 3 & 3 & 4 & 2,5 & 5 & 5 & 3 & 5 \\
\hline Renny & 3 & 3 & 5 & 5 & 2,5 & 5 & 5 & 5 & 5 \\
\hline Dian & 4 & 4 & 4 & 5 & 2,5 & 5 & 3 & 5 & 5 \\
\hline Nurul & 2 & 4 & 3 & 4 & 2,5 & 5 & 3 & 3 & 5 \\
\hline Syahru & 3 & 3 & 3 & 4 & 2,5 & 5 & 3 & 1 & 3 \\
\hline Ferdy & 4 & 4 & 1 & 3 & 2.5 & 5 & 1 & 3 & 5 \\
\hline Ibnu & 4 & 4 & 1 & 3 & 2,5 & 5 & 1 & 3 & 3 \\
\hline
\end{tabular}


Setiap nilai kriteria untuk setiap dosen yang akan di tentukan akan memiliki bobot kepentingan untuk setiap kriteria. Bobot kriteria terdapat pada tabel 4 berikut:

Tabel 4. Bobot Kriteria Penilaian

\begin{tabular}{|l|c|c|}
\hline \multicolumn{1}{|c|}{ Kriteria } & Bobot & $\begin{array}{c}\text { Cost(- } \\
\text { )/Benefit(+) }\end{array}$ \\
\hline Beban Kerja Dosen (SKS) (C1) & 0,1 & $-0,1$ \\
\hline Jumlah Mahasiswa Bimbingan (C2) & 0,1 & $-0,1$ \\
\hline Jumlah Bimbingan Selesai (C3) & 0,15 & 0,15 \\
\hline Kompetensi(C4) & 0,18 & 0,18 \\
\hline Pendidikan(C5) & 0,05 & 0,05 \\
\hline Status Pekerjaan (C6) & 0,1 & 0,1 \\
\hline Pengalaman Pembimbing (C7) & 0,12 & 0,12 \\
\hline Durasi Setiap Bimbingan (C8) & 0,11 & 0,11 \\
\hline Layanan Konsultasi (C9) & 0,09 & 0,09 \\
\hline
\end{tabular}

Perubahan nilai kriteria pada tabel 3 selanjutnya membuat normalisasi matrik vector ( $\mathrm{Si}$ ) dengan mencocokkan antar kriteria dengan alternatif yang ada. Dengan menggunakan persamaan 1 dapat menghitung Normasilasi matrik. Hasil akhir dari normalisasi matriks ditunjukkan pada Tabel 5.

Tabel 5. Hasil Normalisasi Vektor S (Si)

\begin{tabular}{cccccccccc}
\hline \multirow{2}{*}{ Name } & C1 & C2 & C3 & C4 & C5 & C6 & C7 & C8 & C9 \\
& Cost & Cost & Benefit & Benefit & Benefit & Benefit & Benefit & Benefit & Benefit \\
\hline Ilham & 0,50 & 1,00 & 0,60 & 0,80 & 1,00 & 1,00 & 1,00 & 0,60 & 1,00 \\
Renny & 0,67 & 0,67 & 1,00 & 1,00 & 1,00 & 1,00 & 1,00 & 1,00 & 1,00 \\
Nurul & 0,50 & 0,50 & 0,80 & 1,00 & 1,00 & 1,00 & 0,60 & 1,00 & 1,00 \\
Dian & 1,00 & 0,50 & 0,60 & 0,80 & 1,00 & 1,00 & 0,60 & 0,60 & 1,00 \\
Syahru & 0,67 & 0,67 & 0,60 & 0,80 & 1,00 & 1,00 & 0,60 & 0,20 & 0,60 \\
Ferdy & 0,50 & 0,50 & 0,20 & 0,60 & 1,00 & 1,00 & 0,20 & 0,60 & 1,00 \\
Ibnu & 0,50 & 0,50 & 0,20 & 0,60 & 1,00 & 1,00 & 0,20 & 0,60 & 0,60 \\
\hline
\end{tabular}

Hasil normalisasi pada Tabel 5 kemudian akan dilakukan perkalian dengan bobot kriteria yang diberikan oleh decision maker yaitu kepala jurusan yang terdapat pada Tabel 4 untuk mencari nilai variansi setiap alternatif. Nilai variansi vektor (Vi) diperoleh menggunakan Persamaan 2. Hasil perhitungan nilai variansi alternatif beserta peringkat masing-masing alternative dapat dilihat pada table 6 sebagai berikut:

Tabel 6. Perhitungan Nilai Variansi Alternatif Beserta Peringkat

\begin{tabular}{|c|c|c|c|}
\hline & Nilai S & Nilai V & PERINGKAT \\
\hline Ilham & 2,391613674 & 0,163343895 & 3 \\
\hline Renny & 2,809960744 & 0,191916419 & 1 \\
\hline Nurul & 2,412982396 & 0,164803349 & 2 \\
\hline
\end{tabular}




\begin{tabular}{|c|c|c|c|}
\hline Dian & 2,249412881 & 0,153631778 & 4 \\
\hline Syahru & 1,881499902 & 0,128503832 & 5 \\
\hline Ferdy & 1,481339034 & 0,1011734 & 6 \\
\hline Ibnu & 1,414777288 & 0,096627325 & 7 \\
\hline
\end{tabular}

\section{KESIMPULAN}

Metode Weighted Product (WP) dapat diterapkan dalam menentukan dosen pembimbing dan penguji skripsi. Selaian itu dengan adanya Sistem untuk menentukan dosen pembimbing dan penguji skripsi yang terintegrasi antara pengguna sistem satu dengan lainnya memberikan kemudahan kepada Administrasi dan decision maker yaitu Ketua Jurusan Sistem Informasi untuk dapat memberikan penilaian secara komprehensif dan terkomputerisasi berupa hasil ranking dosen yang akan menjadi pembimbing dan penguji serta memberikan solusi untuk meningkatkan pelayanan dan kinerja pihak jurusan dalam mengelola data yang mempercepat alur saat menentukan dosen pembimbing dan penguji secara online tanpa harus melalui rapat internal jurusan. Dan terakhir dengan sebuah sistem informasi terkomputerisasi yang mempunyai basis data yang saling terhubung sebagai media penyimpanan data serta pengelolaan arsip dokumen berupa data dosen pembimbing, data dosen penguji, data skripsi mahasiswa, dan laporan berita acara skripsi.

\section{SARAN}

Saran pengembangan untuk penelitian selanjutnya adalah penambahan jumlah alternative dosen pembimbing dan kriteria yang digunakan sebagai penilaian untuk menegaskan kembali bahwa metode WP memang lebih relevan untuk diterapkan pada sistem penentuan dosen pembimbing tugas akhir. Selain itu perlu juga dilakukan analisis perbandingan pada metode metode perhitungan DSS yang lainnya guna menunjukkan hasil yang berbeda.

\section{UCAPAN TERIMA KASIH}

Ucapan terima kasih kepada Universitas Tanjungpura melalui Lembaga Penelitian dan Pengabdian kepada Masyrakat yang telah memberi pembiayaan program Penelitian Dasar DIPA Universitas Tanjungpura (PD2U) ini.

\section{DAFTAR PUSTAKA}

[1] Jurusan Sistem Informasi Fakultas Matematika dan Ilmu Pengetahuan Alam Universitas Tanjungpura, Buku Pedoman Penulisan Tugas Akhir. 2020.

[2] D. A. Tohardi, 2019, Pengantar Metodologi Penelitian Sosial + Plus. Pontianak: Tanjungpura University Press. 
[3] Z. Alamsyah and D. Gustian, 2019, "Sistem Pendukung Keputusan Menggunakan Metode Weighted Product dan Simple Additive," Sist. Pendukung Keputusan Menggunakan Metod. Weight. Prod. dan Simple Addit., Vol. 3, No. 1, pp. 129-137, [Online]. Available: http://journals.upi-yai.ac.id/index.php/ikraithinformatika/article/view/310.

[4] A. Abdullah and M. W. Pangestika, 2018, "Rancang Bangun Sistem Pendukung Keputusan Dalam Pemilihan Dosen Pembimbing Skripsi Dengan Metode AHP di UM Pontianak," Cybernetics, Vol. 2, No. 02, p. 234, doi: 10.29406/cbn.v2i02.1297.

[5] H. Situmorang, R. Sitanggang, B. Darmanik, and Immanuel H Manurung, 2020. "Pengambilan keputusan Berbasis Komputer Dengan Metode Simple Multi Attribute Rating Technique Dalam Menentukan Dosen Pembimbing," J. Comput. Engeneering Syst. Sci., Vol. 5, No. 2, pp. 210-215.

[6] I. Septiana, M. Irfan, A. R. Atmadja, and B. Subaeki, 2016, "Sistem Pendukung Keputusan Penentu Dosen Penguji dan Pembimbing Tugas Akhir Menggunakan Fuzzy Multiple Attribute Decision Making Dengan Simple Additive Weighting (Studi Kasus: Jurusan Teknik Informatika UIN SGD Bandung)," J. Online Inform., Vol. 1, No. 1, p. 43, doi: 10.15575/join.v1i1.10.

[7] F. H. Purba, 2019, "Sistem Pendukung Keputusan Dalam Menentukan Dosen Pembimbing Skripsi Fakultas Teknik Informatika Universitas Islam Sumatera Utara Menggunakan Metode Weighted Product (WP)," J. Inf. Syst. Res., Vol. 1, No. 1, pp. 5462.

[8] R. A. N. Putri, A. A. Supianto, and W. Purnomo, 2019, "Sistem Pendukung Keputusan Untuk Penentuan Dosen Pembimbing Skripsi Menggunakan Algoritme WinnowingWeighted Product," J. Pengemb. Teknol. Inf. dan Ilmu Komput., Vol. 3, No. 9, pp. 9132-9138,

[9] A. Stephano and R. Puspita Sari. 2018, "Sistem Pendukung Keputusan Dalam Penerimaan Karyawan Menggunakan Metode Weighted Product," in Seminar Nasional Sisfotek, pp. [Online]. 14-25, Available: http://seminar.iaii.or.id/index.php/SISFOTEK/article/view/51/41.

[10] D. I. Samidah and Dahrizal. 2014, Pedoman Penulisan Karya Ilmiah. Depok: PT. RajaGrafindo Persada.

[11] D. Nofriansyah and S. Defit, 2017, Multi Criteria Decision Making (MCDM) pada Sistem Pendukung Keputusan, Deepublish, Yogyakarta.

[12] T. M. , A. S. S. , Nurul Mutiah. 2020, "Tata Kelola Manajemen Aset TI Menggunakan Framework Cobit 5 dan Itam," Coding J. Komput. dan Apl., Vol. 8, No. 2, doi: 10.26418/coding.v8i2.41264.

[13] M. Muslihudin, Oktafianto, and H. Sri, 2016, Analisis dan Perancangan Sistem Informasi Menggunakan Model Terstruktur dan UML. CV. Andi Offset, Yogyakarta. 